\title{
Visual pollution phenomena and sensitivity of residences in heritage city centers Case of: Old district of Manama city, Kingdom of Bahrain \\ * Dr. ISLAM EL-GHONAIMY
}

Department Of Architecture and interior design, College of Engineering, University of Bahrain, Bahrain E mail: eelghonaimy@uob.edu.bh

\begin{tabular}{l}
\hline A R T I C L E I N F O: \\
\hline Article history: \\
Received 08 February 2018 \\
Accepted 15 May 2018 \\
Available online 25 August \\
2018 \\
\hline Keywords: \\
Building façades; \\
Commercial life-; \\
Atheistic and \\
Beautification; Visual \\
discomfort
\end{tabular}

This work is licensed under a Creative Commons Attribution - NonCommercial - NoDerivs 4.0. "CC-BY-NC-ND"

\begin{abstract}
A B S T R A C T
Image of the ancient cities across the Arab region have been changed. The urbanization progress and their subsequent urban changes are of rapid acceleration, due to the population increase in the named cities; affecting the encompassed old districts in many respects. The mentioned changes are forked into two main branches; controlled and uncontrolled. On one side, the controlled category abide by the urban regulations in terms of the visual representation of the old districts. On the other side, the uncontrolled counterpart breach these regulations and their logical assumptions ending up in many urban problems in general and visual pollution in particular. The objective of this research is to tackle those cases of visual pollution. The research methodology is staked on both of the data collection and theoretical background about old district in Manama City, whereas thorough historic background of the city and analytical studies of the selected data and questionnaire are carried out. Although there were a few open-ended questions, the majority were closed-ended taking the form of yes/no, multiple choice, or rating scales. Questions went through several renditions based on intra- and interdepartmental review before being presented.
\end{abstract}

JOURNAL OF CONTEMPORARY URBAN AFFAIRS (2019), 3(1), 175-190.

https://doi.org/10.25034/ijcua.2018.4694

www.ijcua.com

Copyright (c) 2018 Journal Of Contemporary Urban Affairs. All rights reserved.

\section{Introduction}

Treading along these ancient cities compels any researcher for visual quality analysis purposes. Albeit, touring across their streets is quite sufficient, to observe the devastating alteration within their urban state deforming their urban texture and architectural structure equivocally. It is way facile to track and detect the distinctive architectural set up of the buildings in regard of their affiliation to various decades. In addition, it is easy to the development of these cities and the lifestyle of its residents by examining the adjustments of their building volumes, forms, color, height, and design. (Elghonaimy, Environmental Assessment of Urban Area, 2000).

In Bahrain, old district of Manama city is a

*Corresponding Author:

Department Of Architecture and interior design, College of

Engineering, University of Bahrain, Bahrain

E-mail address: eelghonaimy@uob.edu.bh 
witness on the economic, political and social eventuated over the last decade for Manama has been always the heart of civilization and vitality in Bahrain for a long time interval. It is acknowledged that the municipal architecture mirrors the cultural identity, social standard, political conditions and economic status of the homing civilization. Therefore observing the building chronological sequence in Manama indicates the sovereign historical eras of the Bahraini civilization.

It is a worth inspecting issue since the local residences of the ancient cities; Manama rely on their accommodating buildings in all their daily urban routine; living, trading, commercial activities, entertainment and social services in terms of education and health, to name a few. Yet architecture is taken for granted as part and parcel of our existence whereas it is not receiving enough attention nor contemplation. Nevertheless, considering architecture as an intrinsic part of our existence, then it ought to be enhanced regarding the visual quality of cities and counted as a window to its hosting cultural identity and its residents' self-esteem.

\subsection{Diagnosis of the problem}

Many urban problems occur due to malfunctioning treatment of old districts in cities, such as; overpopulated residential areas, infrastructure deficiencies, and indiscriminate distribution of city services deteriorating the life quality right there. The foreign workforce imported utilize the spaces as per their requirement and understanding, thereby altering the prime functions of spaces. Moreover, they are reluctant about the visual display of their place of inhabitance as they do not consider that it belongs to them and they know that their stay is temporary. Visual pollution has been the ultimate repercussion of the haphazard urbanization policy adopted in old district of Manama.

\subsection{Significance of studying "Manama city}

Manama is the former capital of Bahrain, besides. It is considered as a prime tourist attraction and investment zone. It has been the prime location in the past for activities and still holds its position as an important city of Bahrain. The factual image of Manama incarnates the status of Bahrain in general indicate that of Bahrain. Manama is the considered the hub of the social, economic and environmental issues in Bahrain.

\subsection{Motivation of selecting "old district of Manama "as case study}

Old district of Manama city is the core business activities and official buildings of Ministries in Bahrain. Moreover, it is rich in archaeological monuments and heritage architecture entities. Enhancing the visual quality would positively show on residents' life quality, and attract investors to do business activities and tourists to visit the heritage areas, which by turn improves the national economy of Bahrain.

\subsection{Research Idea}

The unsorted conflict between Bahrain 2030 regarding the enforced regulations and actions amongst local authorities degrades the visual quality in the old district in Manama city. The flow of this conflict should be curbed, to avoid downgrading the visual quality in old district of Manama.

\subsection{Aim of the research}

To find out the reasons of the deterioration of the visual quality in the old district of Manama, and the forms of the resulted visual pollution then how can we enhance it, which consequently will

- influence positively life quality of residences

- $\quad$ attract capitals of business

- Encourage tourists to visit the heritage areas,

Consequently, will leads to improve the economy of Bahrain

\subsection{The research methodology}

Research methodology consists of two cardinal sections, where the first compromises the theoretical background figuring out the motif of adjusting the urban texture of Manama followed by a survey interviewing its users, residences, businessmen and municipality officers. The second demonstrates the analytical phase concerning the collected data and the findings of the interview to generate the research guidelines.

\section{Visual pollution problem in old cities 2.1. Definitions}

In general, visual pollution is an aesthetic issue referring to the impacts of pollution that impair one's ability to enjoy a visit or view. Visual pollution is defined as the whole of irregular formations, which are mostly found in natural and built environments. (Yilmaz, May 2011). It could be also defined as encountering unfavorable sight that flaunts the aesthetic appeal of a specific area. Visual pollution 
occurs when an individual cannot enjoy the view in a particular area due to the drastic changes taking place in a named natural environment.

\subsection{Old districts and Urban Design Defects:}

In old districts in cities, life style change affected the physical conditions of the urban plan in general moreover, architectural representation in particular. In Manama, by the oil mining success and modernization, most of the old residences moved out the old districts towards new districts looking for modern and more comfortable and spacious areas. Fascinated by their desire to lodge in the new residencies together with their unawareness of the value of the abandoned ones led to sweeping downfall of the old Manama and its traditional buildings as well. This reality has changed the character of the human settlement in these old areas depending on the variations of circumstances, actions and events such as migration and employment, balance of urban fabrics. (Hamouche, 2009)

In order to reconcile visual quality inside old district efficiency with physical and environmental constraints, the performance of policy and strategies in old cities seeking urban development needs to be monitored and evaluated. Reconciling visual quality inside old district efficiency required improving the quality of life reflect upon visual quality. The key factors of Reconciling coming from clarifying the value of these old districts and avoiding the conflict between policy and action plans. (Elghonaimy, Environmental Management and Economic, 1995). En masse, the planning process has to meet specific goals in terms of users, time and space. Behavior of the users' forces cannot always be predicted, so feedback information is necessary to reevaluate initial goals and objectives. The main features affected by the deterioration of urban quality are building condition, quality of life and standard of living. (Dalia Hussain El-Dardiry, Islam Hamdi Elghonaimy, 2010) The parallel impacts came in term of visual quality in old Manama city.

In many cases, failing in controlling visual pollution because of facing the economic power of business. For examples, as businesses look for ways to increase the profits, cleanliness; architecture, logic and use of space in archaeological urban areas are suffering from visual clutter. (Morozan, Cristian; Enache, Elena; Purice, Suzan., 29 March 2013).

\subsection{Repellent factors in Site Attraction Sceneries}

Visual formation is considered one of the significant factors, to get a full visual picture of cities in general. In old districts, traditional buildings are of unique characteristics. The major factors that affect visitors' scene for this area as follows:

- Site Treatment

- Study of visual interrelation between the buildings and surrounding outdoor spaces

- Site Furnishing

- Artistic element within the urban areas

\subsubsection{Site Treatment}

Street furniture plays significant factor in enhancing the visual communication between existing buildings and urban fabric. In old part of cities, visual studies take to embark the site treatment. It could be working on underscoring and preserving its nature, obliterating whatever spoils its homogenous set up. Moreover, it aims at introducing some additives, to highlight its natural composition on the one hand. It may be also an attempt to demolish this set all together or work on amending adjustments on the other.

\subsubsection{Study of Visual Interrelation between the Buildings and Surrounding Outdoor Spaces}

It comes second after the treatment process, where the buildings are studied as one block or limited variable ones. Thus, the visual image formation is not hard to handle. Using similar colors, details and materials end up in a homogenous rhythm along the blocks and spaces. It may be apparent in a systematic train of thought in control of the design; hence, the visual interrelation among the constituents of the site especially for those speedy highway travelers, for speed is known for correlating the nearest points to the farthest ones. Therefore, the named goal is realized.

Regarding free designs, they are doubleedged weapon for their free block formation though their main problem lies in achieving continual block-space interrelation with variant functional surroundings. The design is termed successful, if it satisfies the spectators visually and psychologically meeting their expectations and satisfying their wants, bearing in mind their individual differences. Reaching out for this continuation and consistency, exaggerated repellent forms and size blocks must be cut down along with setting forth an overall controlling visual theme. This is either achieved by areal categorization; narrow 
ranged areas must be separated from their wider counterparts, or opting for green areas and foresting for thematic supremacy.

\subsubsection{Site Furnishing:}

It is a crucial supplementary factor for completing the site scene in archaeological areas. The comprehensive site scene includes plants, fountains, lighting and other artistic factors, ruling out any repellent forms for homogeny purposes. Additives do maintain the color scheme and aesthetic touch necessary for an architectural design, yet they decrease the feeling of heat in high temperature areas, meanwhile they are despised in highly humid zones. Therefore, we can say that Site furniture is not of a sole visual function, but comprehensive seen as well.

Thus, their quantity and types must be allocated according to the homing environment circumstances in days and nights equally. From climatic perspective, regularly Bahrain is overwhelmed by sand storm. Thus site furnishing is also significant in enhancing the visual quality in sand storm attacked zones, for dust deposition areas, where evergreens perfectly fit, for their dropping foliage accumulates no snow. (Chmielewski, Sz., Lee, D., Tompalski, P., Chmielewski, T., J., Wężyk, P, 2016)

\subsubsection{Artistic Element within the Urban Areas:}

There are other elements that in crucial dense such as statues, sculptures. They connect different spaces and interfere in the curvature of the corridors in directing and clearing probable congestions within the site as well as the grading steps, kiosks, shops and billboards, in respect to the design consistency and the site visual coherence. (Elghonaimy, Historical preservation projects and urban developing plans, Impacts of Successful experiments in historical preservation projects upon Enhancing City urban conditions; Case of Bahrain, 2011).

\section{Case Study: Governorate Road, "Bab Al Bahrain"}

\subsection{Historical Background}

Bahrain has a prolonged history that goes back to before the birth of Christ era, where the oldest civilization took place "Delmon"; it was a center of trading from that time, until today. Till the time being, trading background still influences the Bahraini community. Manama is one of the most old cities in Bahrain emerged in 1780s, where Manama is the capital and largest city of Bahrain, it was an important trading center in the Gulf. Traders came to rest and feature their products. It means "the place of rest", Manama is a cosmopolitan castle embracing multi-ethnic origins within; Jews, Muslims, Christians, Hindus Buddhists, etc. It has been a melting pot for all these ethnic varieties lived door to door since the birth of the peaceful coexistent community

The case of studying locate in the old district Manama, Governorate Road, "Bab Al Bahrain" area. This Avenue is one of the liveliest streets in Bahrain, it is filled with locals and tourist filling this area, with Bab-AL Bahrain and the gold market is one of the busiest streets in Manama. Visual analysis will for this street to find out the common features of visual pollution then in return, it would be requesting some improvements that may enhance the users' experience. (Hamouche, 2009).

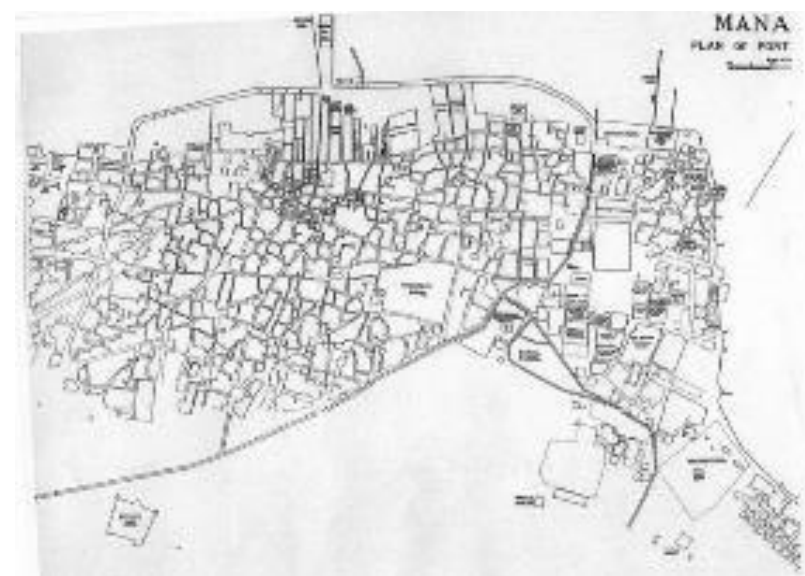

Figure 1. A map of Manama of the early ' 30 s clearly show the morphological structure and the extent of the two fabrics at the beginning of the modernization process (Agriculture, 2007)

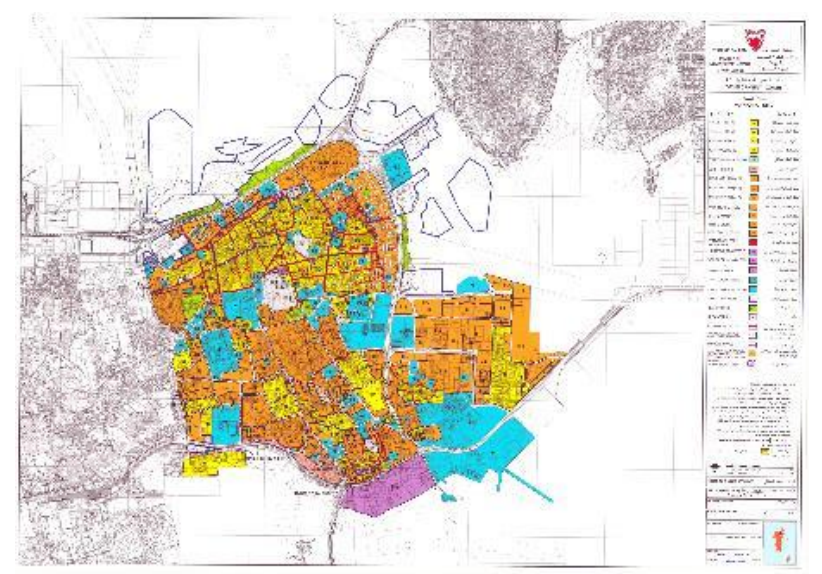

Figure 2. A map of Manama governorate clearly show the old district, Bahrain, in 2016s, Ministry of Municipalities Affairs and Agriculture

A sample of "transitional area" in Manama; the historic pattern is still kept, but some streets have been widened to become commercial trough fares. Several transformations have occurred in the built-up fabric as well, 
especially along the "modernized" streets. The red perimeter show the survey test area.

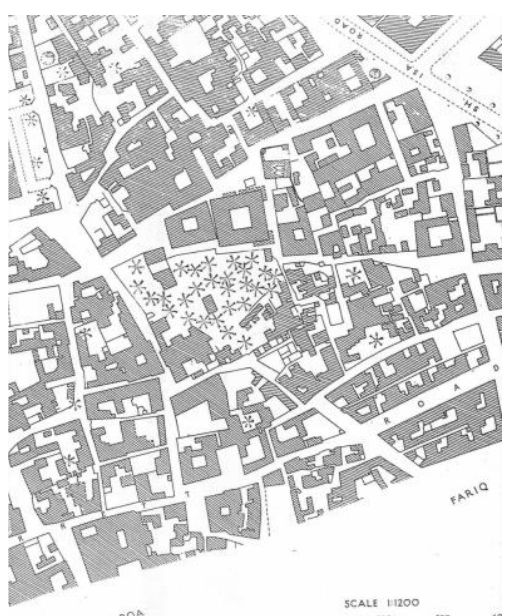

Figure 3. A portion of Manama city, Bahrain, in 1950s showing the urban fabric and spaces usage in old district (Hamouche, 2009)

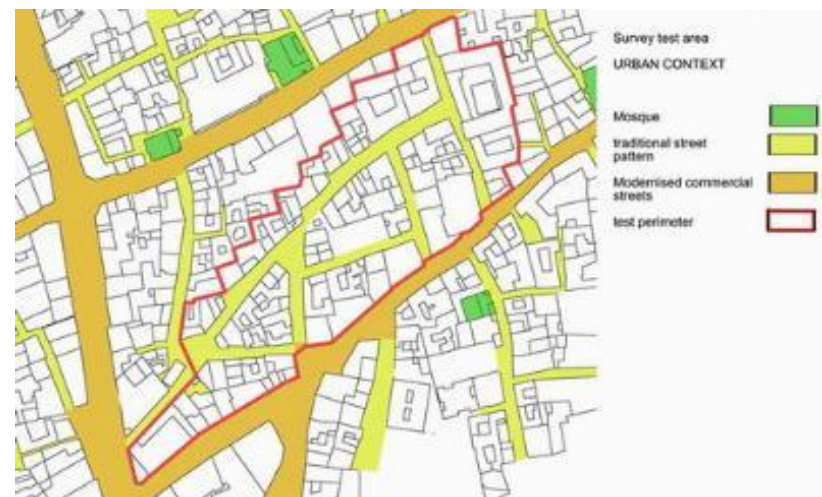

Figure 4. A portion of Manama city, old district 2006 showing more focus the urban fabric and spaces usage in old district (Agriculture, 2007)

The survey test area in the "transitional" zone: a "modernized" commercial street and two "traditional" streets. The bases of the survey data (including ownership, state of occupancy, building typology, construction system, and so forth) the category of the permitted interventions are identified for each buildings (left). Some "sensitive" areas can also be defined to be possibly submitted to integrated conservation and regeneration projects. (Agriculture, 2007).

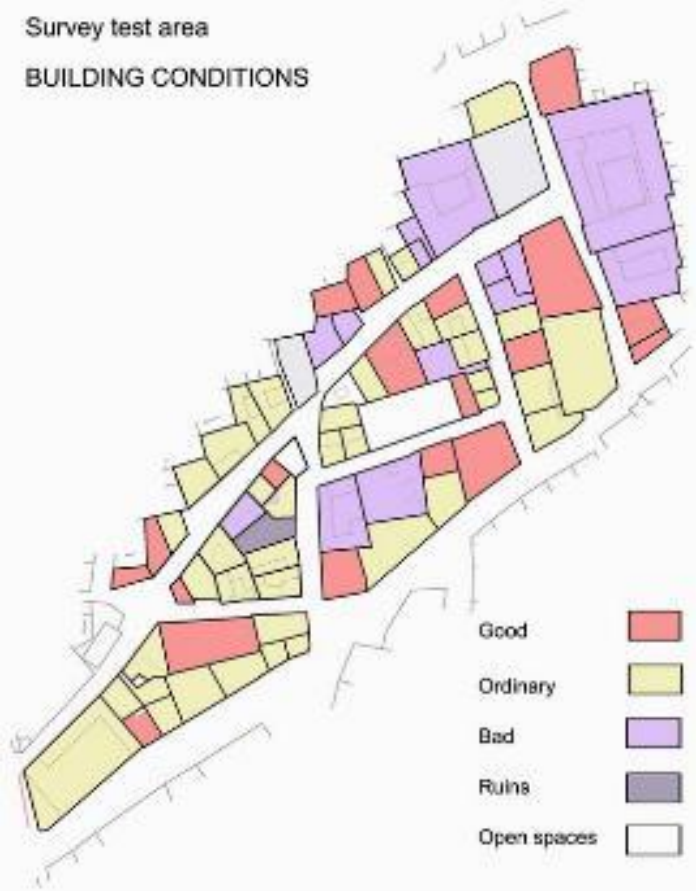

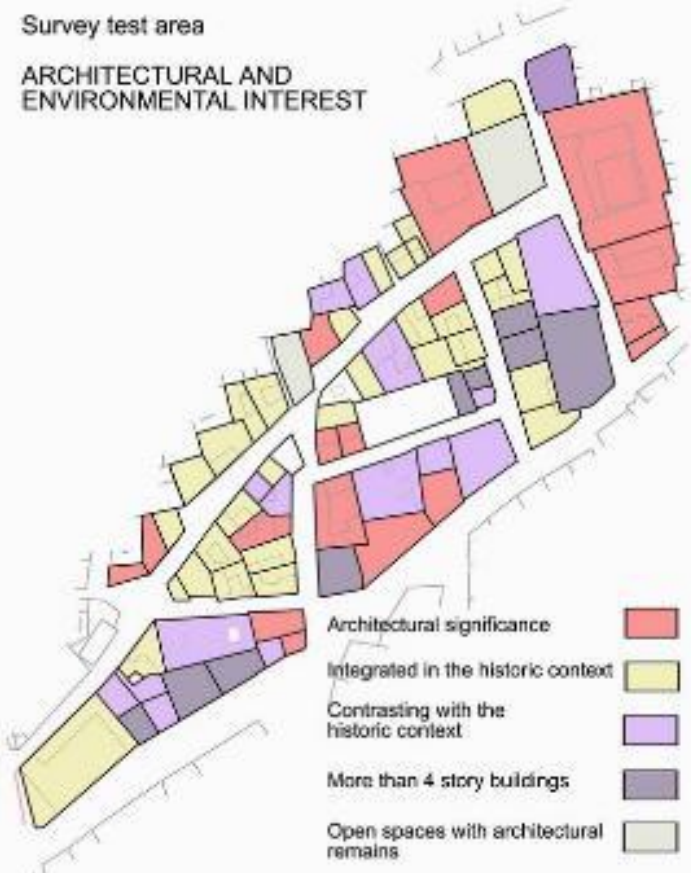

Figure 5. 1The survey test area in the "transitional" zone (Agriculture, 2007) 


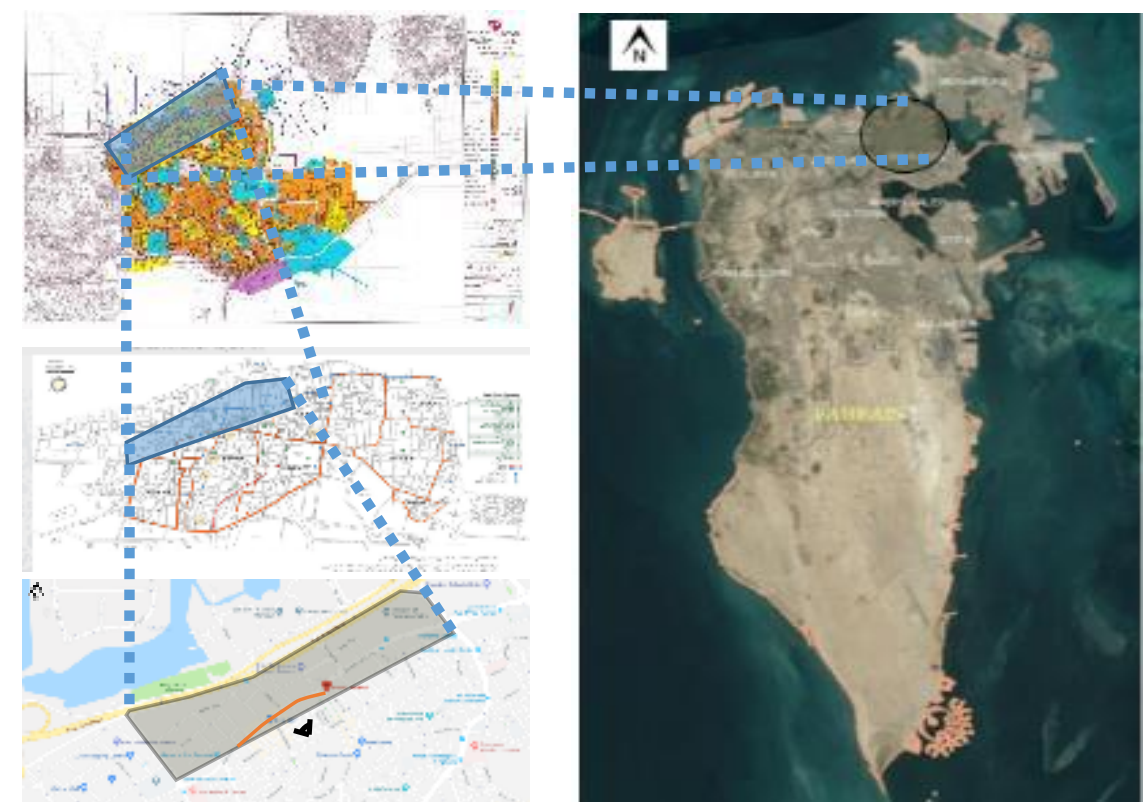

Figure 6. Location of the pilot study of: "Bab Al Bahrain", Governorate Road, Old Manama, Kingdom of Bahrain

\section{Pilot study: Government road, Old district, Manama City}

\subsection{Location of the Pilot study}

It is the Avenue that goes through Bab AlBahrain into Manama. Bab Al-Bahrain was built in 1949, and it has undergone eminent changes over the years but the Ministry of Culture undertook a project to preserve it as a cultural landmark; thus restored it to its former glory and eventually moved its tourism sector offices and visitor's center right into the building. Attached to Bab Al Bahrain is the old Manama Marketplace "Souq". The market is a vibrant collection of number of traditional coffee and shops offering a wide range of goods from gold, textiles, spices, incense,

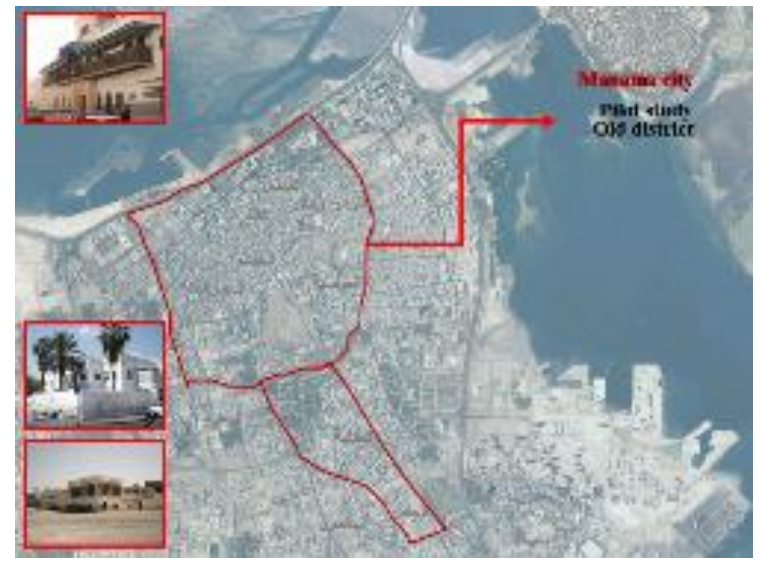

Figure 7. Urban context of the study area, google earth map, 2017 perfumes, handicrafts and souvenirs, as well as more modern products from all over the world. The souq offers a unique shopping experience that brings to mind the style of commerce from days long past (figure 7).

\subsection{Historical background of the Area}

The whole area had gone through many developments until this day; the first area is relatively the same as before. The second area had gone through major changes; it had been turned into a pedestrian path, which is similar to the international case that has been chosen, by turning a normal street into a pedestrian path.

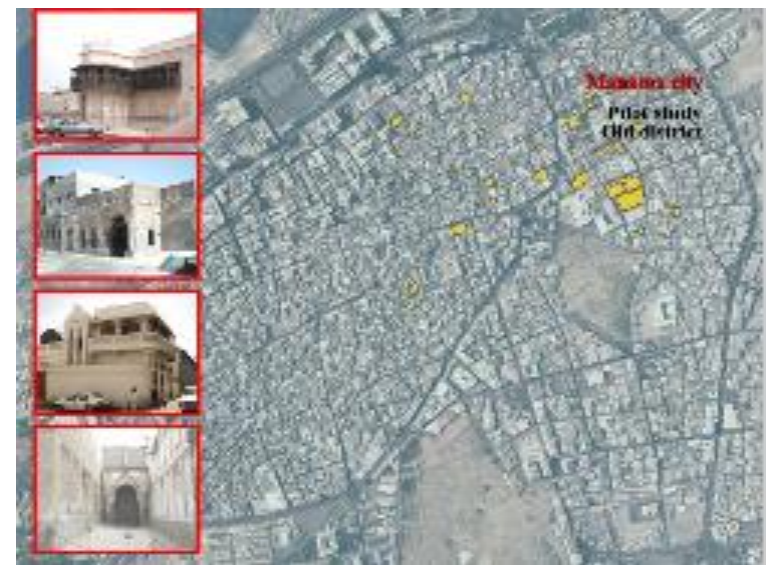




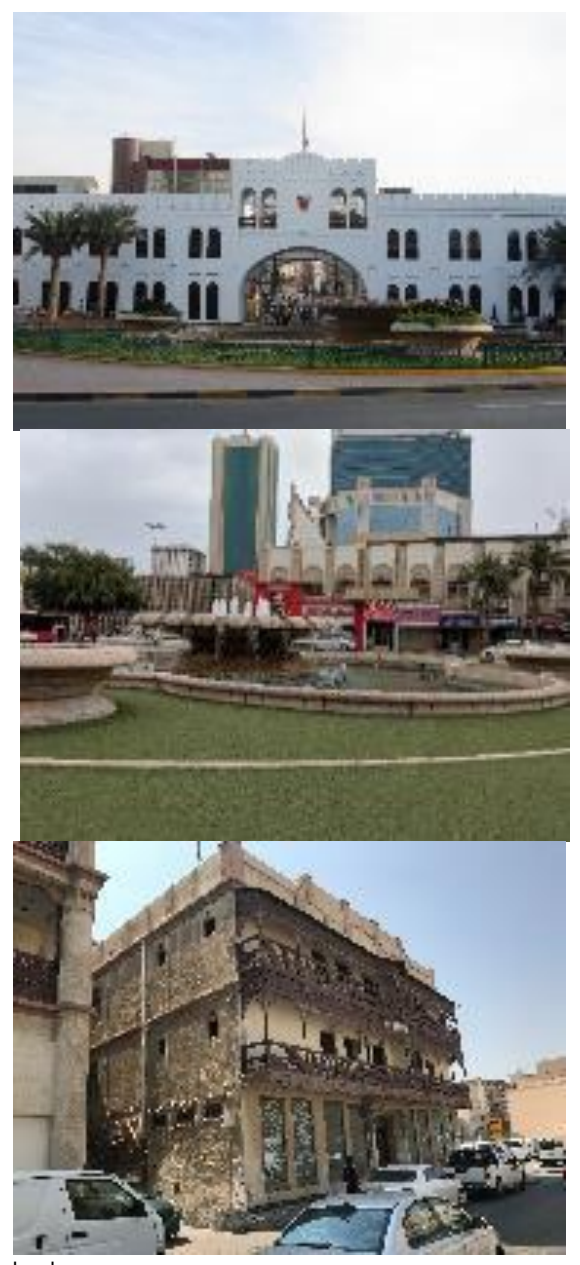

Figure 8. The most famous buildings in the study area.

\subsection{Users}

Fig 9, illustrates the featured estimation for the use of Bab Al-Bahrain Avenue, where it is highest used twice a day; in the afternoon and evening. It records highest utilization rates in the weekends especially Friday. Both inhabitants and tourist use the street, as it holds a cultural attraction as well an economic attraction.

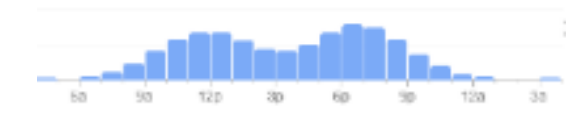

Saturday

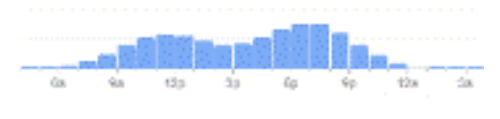

Sunday

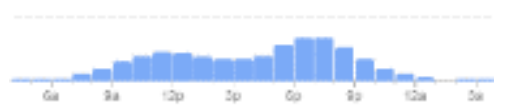

Monday

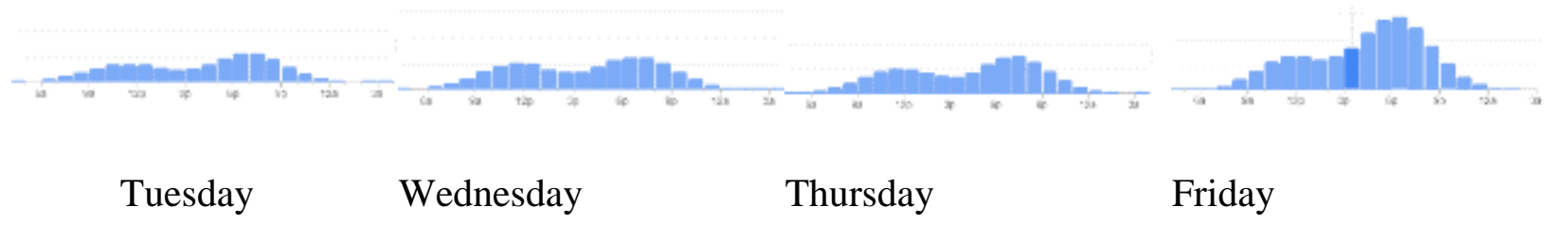

Figure 9. The featured an estimation for the use of Bab Al-Bahrain Avenue (Popular times in Bab Al Bahrain, 2018)

\subsection{Activities}

This area indulges many activities; capturing photos near the (heart) Bahrain structure or near Bab Al-Bahrain or near the hanging coins. For local residences, they can enjoy their time in the cafés they can also sit around and just enjoy the space. While the victors do some shopping and have rest in some traditional cafeterias. 

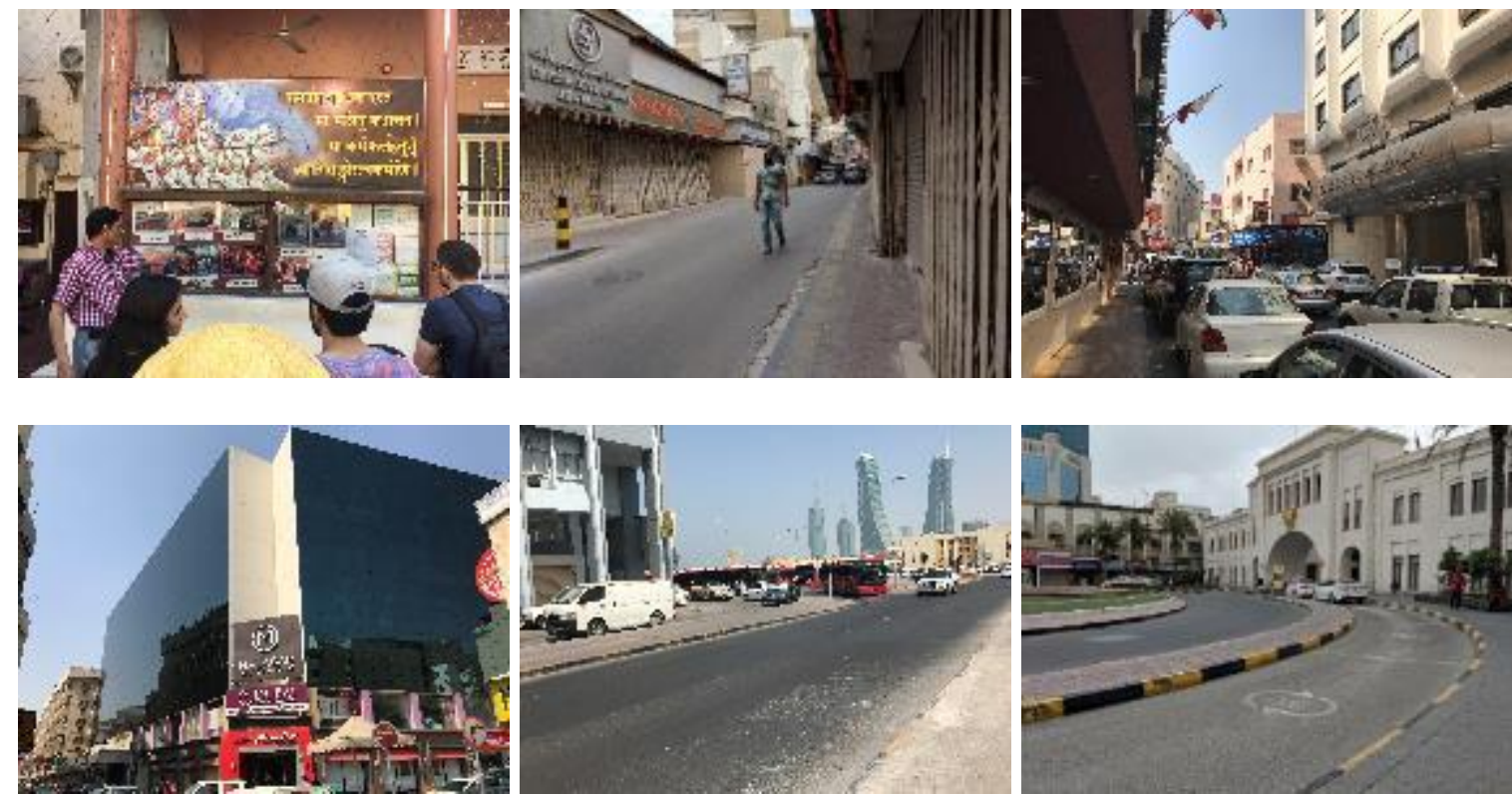

Figure 10. The common social and commercial Activities in the case study area

\subsection{Symptoms of visual pollution in "Bab Al Bahrain", Governorate Road, Old Manama} Unfortunately, the visual quality is deteriorating, which is but a distortion of the once inviting view propagating psychological unease in many places. In particular, the visual pollution appeared due to improper usage of the monumental and valuable wealth of the area disturbing the visual quality concerning its beholders. Infringing changes of the urban context forcing the seers to accept unaesthetic scenes as normal. Residences used to deal with deteriorated visual quality as normal issues. It is an aesthetic issue and refers to the impacts of pollution that impair one's ability to enjoy a vista or view. Visual pollution disturbs the visual areas of people by creating harmful changes in the natural environment. Therefore, the dealing with phenomena of Visual pollution in Manama Old districts is related to its handling methodology.
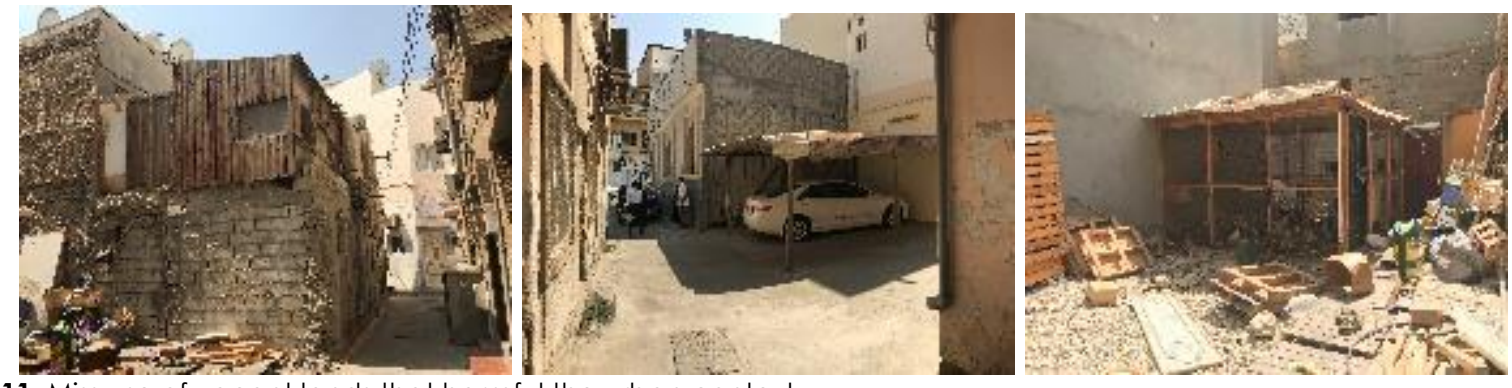

Figure 11. Miss use of vacant lands that harmful the urban context

From the inventory and field survey, it is deduced to be lacking the least artistic taste in dealing with building color or adding new one to the surrounding old buildings or disappearance of the aesthetic image of everything that surrounds from buildings to roads or sidewalks and others will provide some examples of this type of pollution: 


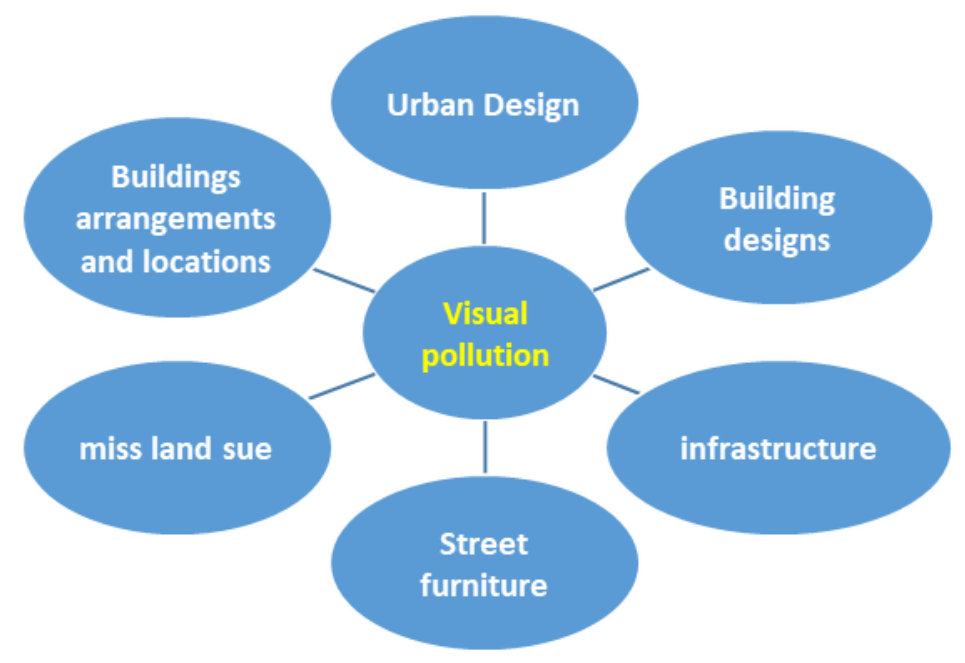

Figure 12. Common causes for visual pollution in study area

\section{a. Urban Design;}

i. Lack of urban controlled: Local managers of old urban areas especially in archaeological places over what is built and assembled in public places.

ii. Poor urban planning of some buildings, both in terms of spaces or in terms of the form of construction.

iii. Build buildings in front of beautiful scenery and hide it, for example hiding the sea

iv. Improper way in hiding waste and countless other examples.

\section{b. Buildings arrangements and locations:}

i. The spread of housing haphazardly in the vacant areas instead of having gardens.

ii. archaeological projects: Deficiency in dealing with the restoration projects in the archaeological areas in comprehensive level

c. Land misuses: in terms of

i. Miss land sue in the old districts in general

ii. open storage of trash, and automobiles movements and parking

iii. Crashed cars or those loaded with goods asymmetrical appearance.

iv. hopheads land use within the area

v. Waste disposals: Garbage cans in their forms that give rise to pessimism. vi. Waste from the rubbish in the land space and around the crankshafts different colors of building facades.

\section{d. Street Furnishings:}

i. Street Lighting: Street lighting poles do not fit the streets while electrical wires are hanging on building' facades deteriorate visual quality of the area.

ii. Poor management of Billboards, Trash cans and dumping areas that are exposed,

iii. Signboards and billboards hanging in the streets in non-matching colors. 


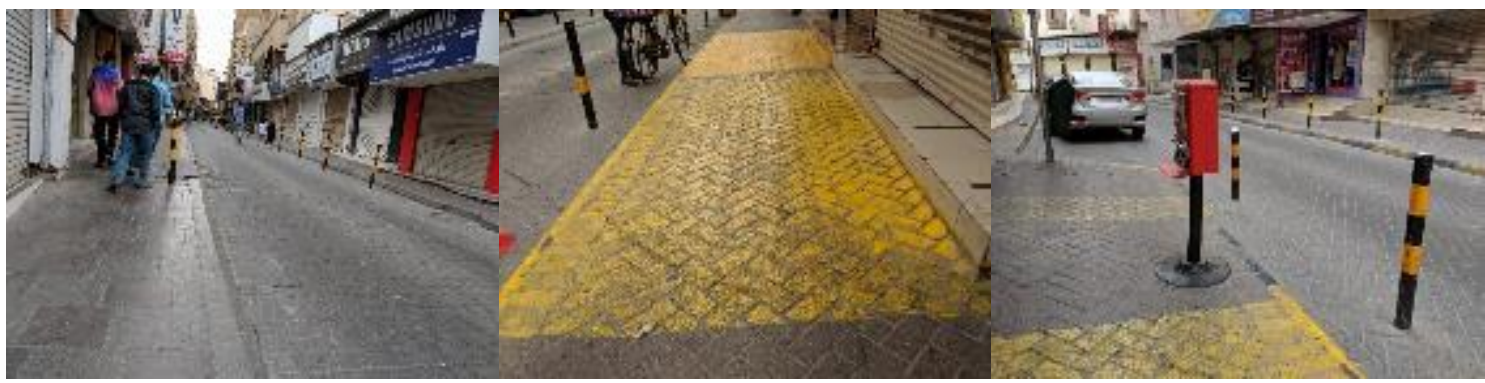

Figure 13. Street furniture: in term of Miss-use Billboards

i. Missing sitting areas and places for taxi drivers waiting areas.

ii. Missing shades and landmarks.

iii. low level of respecting the landmarks for example minor sculpture in the area

iv. Garbage bins: Garbage bins are provided in large numbers (15 or more) and distributed randomly along the street, with different sizes, materials, colors and forms. Pedestrians throw the garbage instead of making the street dirty with wastes.
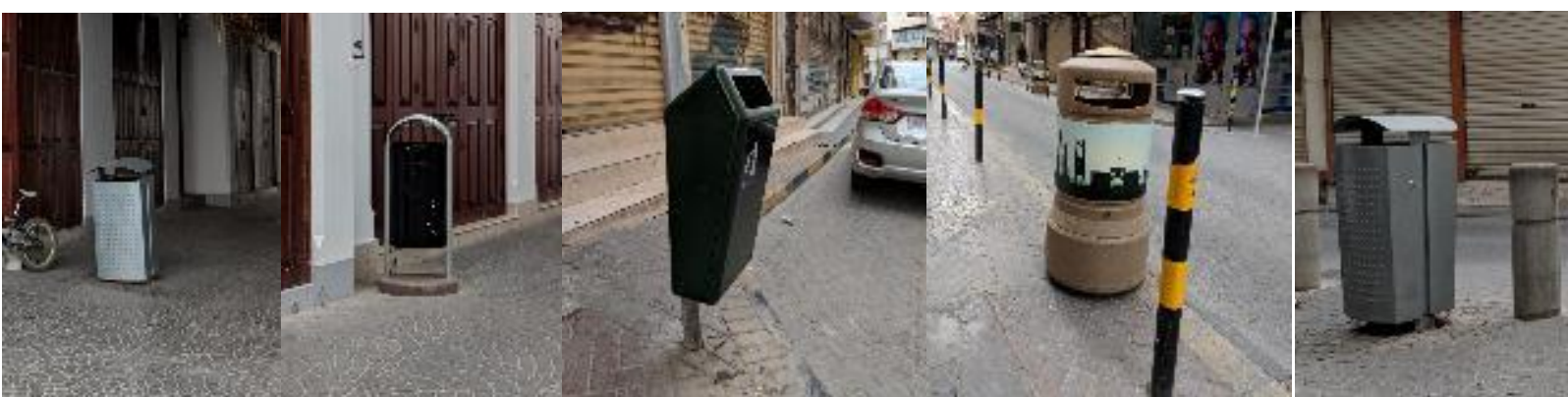

Figure 14. Street furniture: in term of Miss allocating or designing trashcans and dumping areas

v. Fences and Barriers: Lots of barrier structure are used in the avenue to separate the pedestrian pathways from Vehicles Street using these different material and form barriers, so they prevent vehicles to enter some places. Some of these barriers are made of metal; some are made of concrete but in general are not matching with the traditional style of buildings.
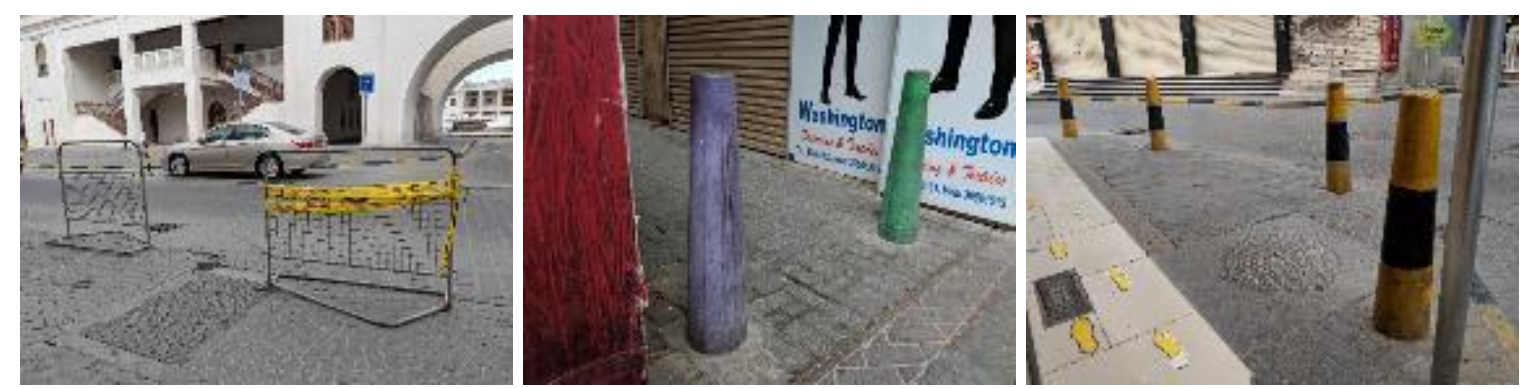

Figure 15. Fences and Barriers are not matching with the traditional style of buildings.

vi. Sitting areas: All visitors of different ages can use sitting areas-the "Basta" sitting area used by adults more. According to time, the using for the areas, all day -used more afternoons and evening as preferable daytime for shopping and using the SOUQ. For taking rest after shopping or for enjoying the photo gallery and the entrance fountain view and for gathering. Shadings in many places are in ugly shape for shading the pathway in the shopping areas and the shading for the police officer. 

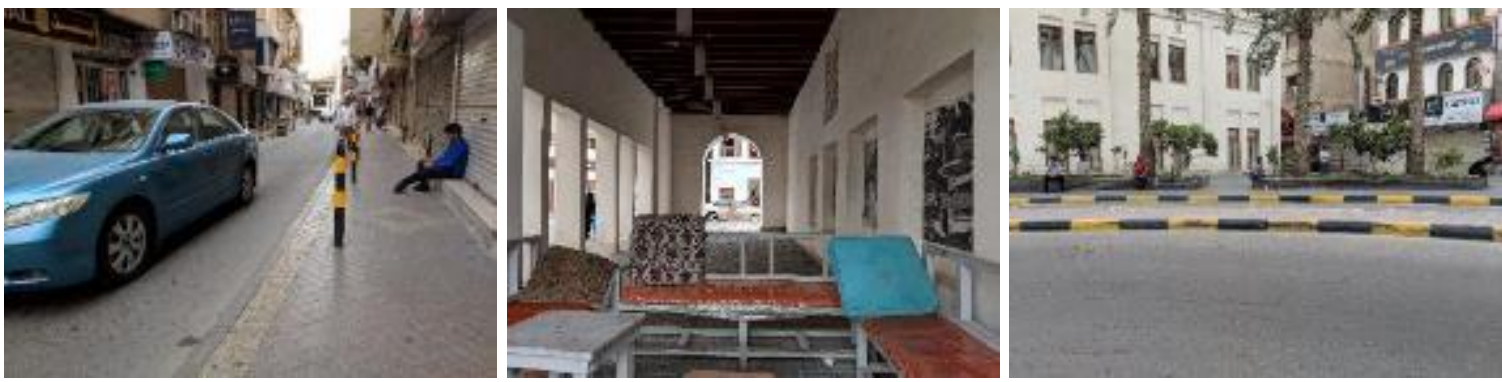

Figure 16. Sitting areas: more visual pollution sources in term of the clear haphazard in allocating for sitting areas.
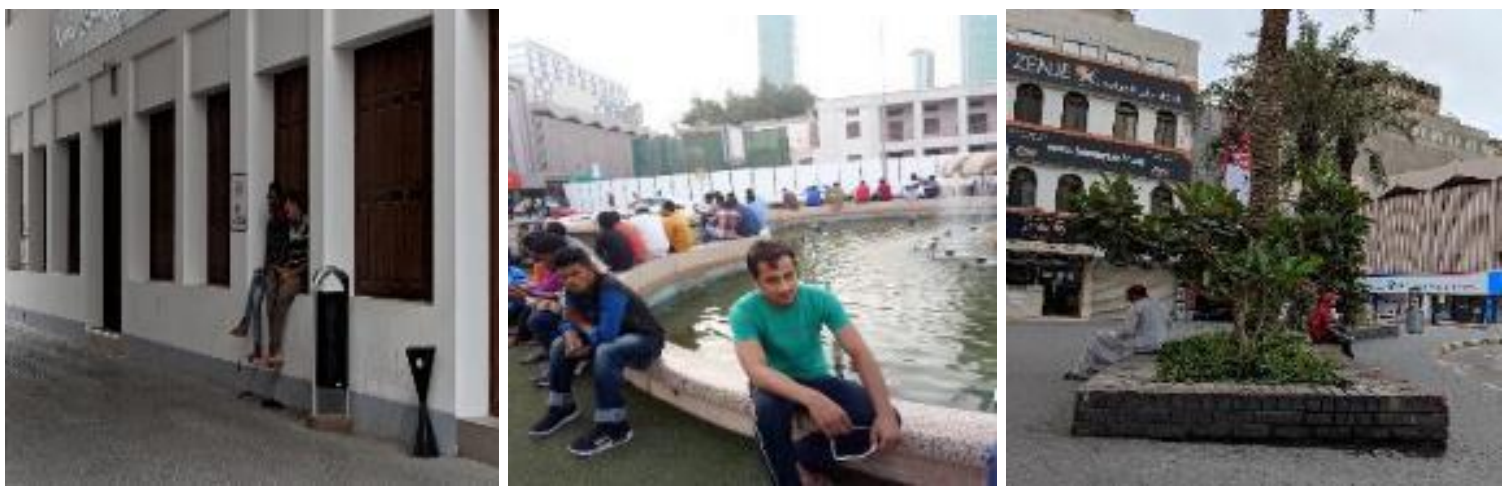

Figure 17. Mal-allocating for sitting areas

vii. shading devises
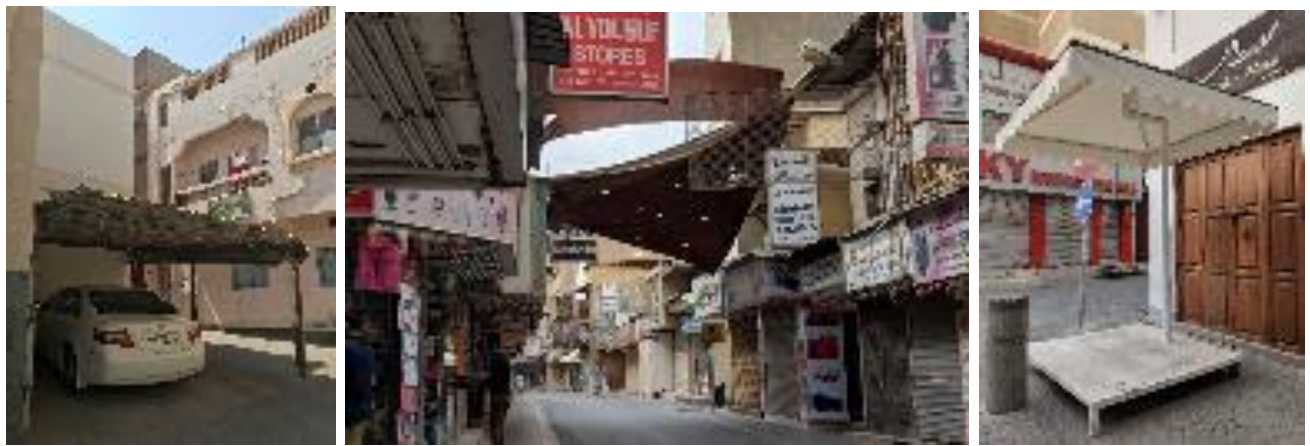

Figure 18. Shadings in many places are in ugly shape

e. Infrastructure: in terms of Antennas, electric wires hanging upon building facades
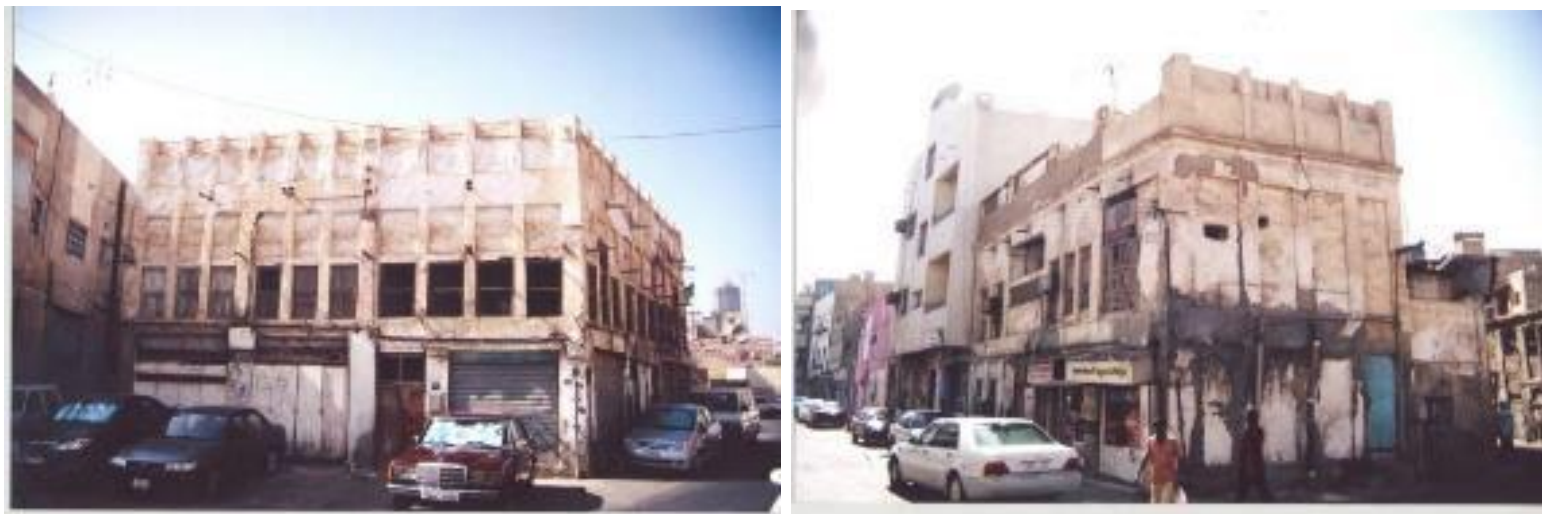

Figure 19. Haphazard car parking with low level of maintenance. 

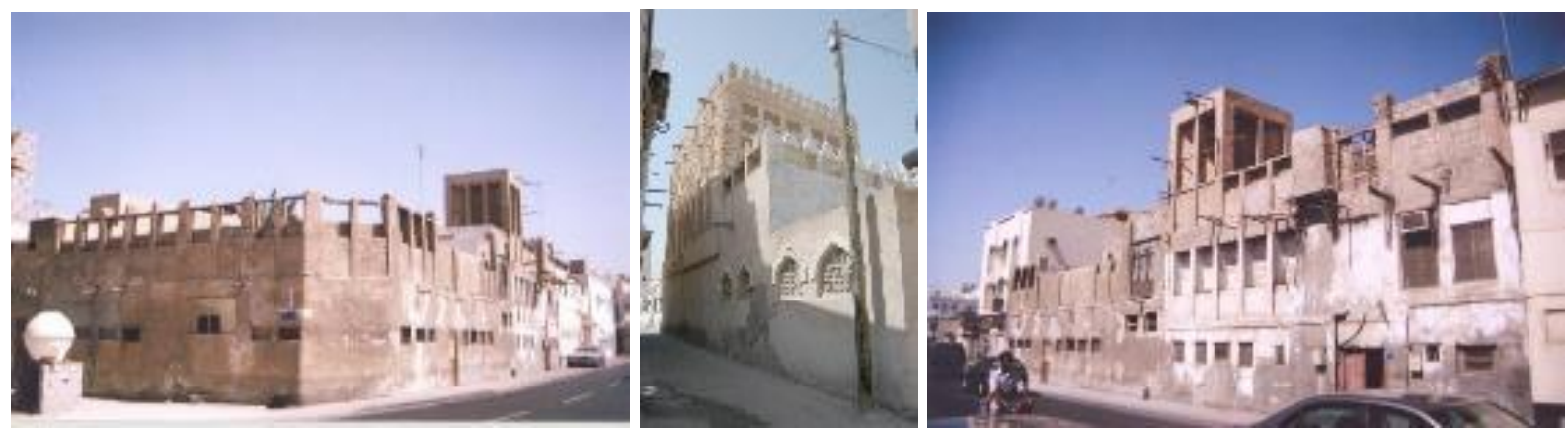

Figure 20: Deteriorating traditional building condition (air conditions are haphazard disrupted).

\section{f. Building designs:}

i. Building heights: Demolishing the traditional buildings amid to build high-rise buildings leads to miss the homogenous skyline for district buildings. Moreover, the creation of new high rise buildings invaded the visual privacy of older homes.

ii. Facades designs: The use of glass and aluminum finishing, which increases the sensation of heat. Moreover, they are randomly hanged for air conditioners in facades.

iii. Colors scheme: lack of harmony for the

iv. Demolishing the traditional buildings to build high buildings.

v. Missing the common style of Architecture design for building in terms of height, color, or design for buildings,

vi. Buildings roofs: Improper use for roofs in term of Antennas or storage are often considered visual pollution. (Chmielewski, S., Samulowska M., Lupa, M., Lee, D., Zagajewski, B, 2018). new parts with the old
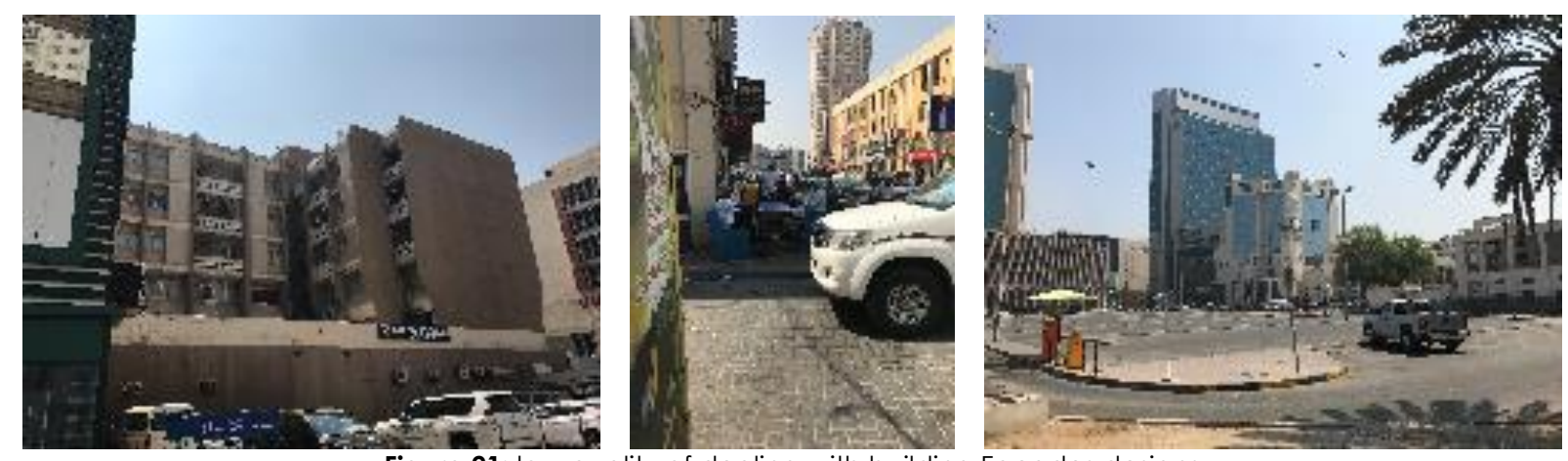

Figure 21: low quality of dealing with building Facades designs

\section{Governmental actions considering visual pollution:}

\subsection{Legislations and regulations}

Several legislations were issued to manage dealing with visual aspects while others were issued to deal with the old districts in Bahrain; like the legal codes in the years 1977, 1979, 1981 and 1998 and binding regulations in the years 1979,-1981, 1988, 1998 and 2005. Unfortunately, not all these laws and regulations controlled the visual pollution or the controlling the deteriorating of the old distrust.

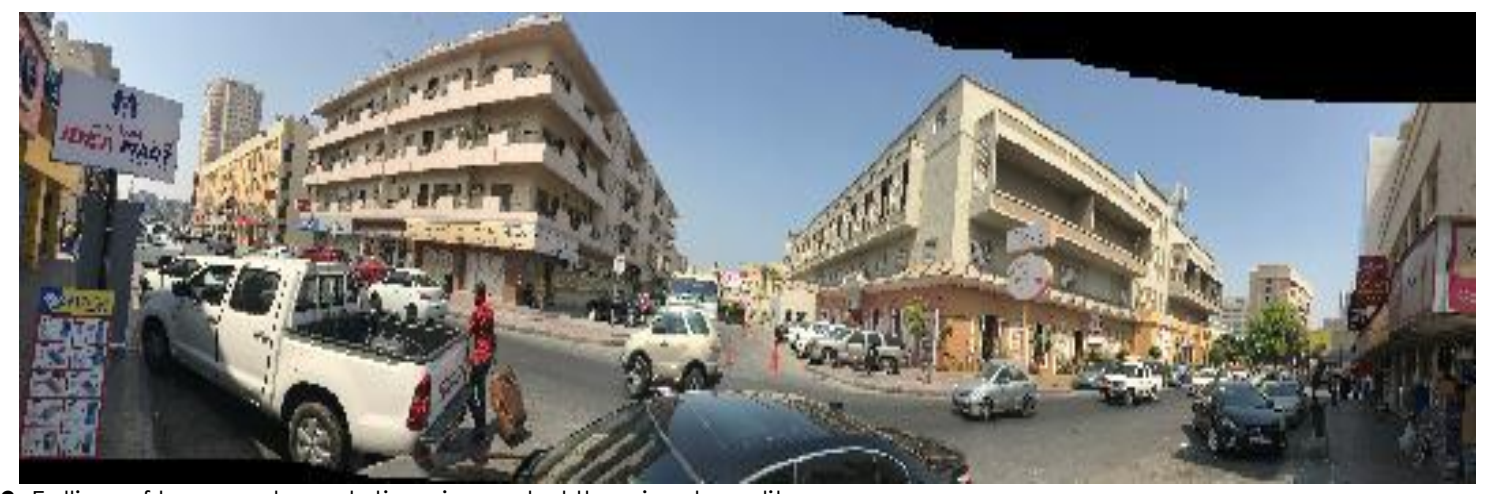

Figure 22: Falling of laws and regulations in control the visual quality. 


\subsection{Bahrain's Master plan 2030 - Overview}

Bahrain's Master plan 2030 deals with the Bahrain Strategies and Policies. There were many steps towards treating visual pollution in old districts in Manama as well for example:

i. Creating one comprehensive master plan for the old district.

ii. Built distinct communities.

iii. "The National Plan of Bahrain lays out key strategies that coordinate and focus development"

- Control Land Speculation

- Protect resources

- Preserve Historical \& Ecological important sites

- Integrate transport \& ensure public access to open space Waterfront. (Bahrain, 2007).

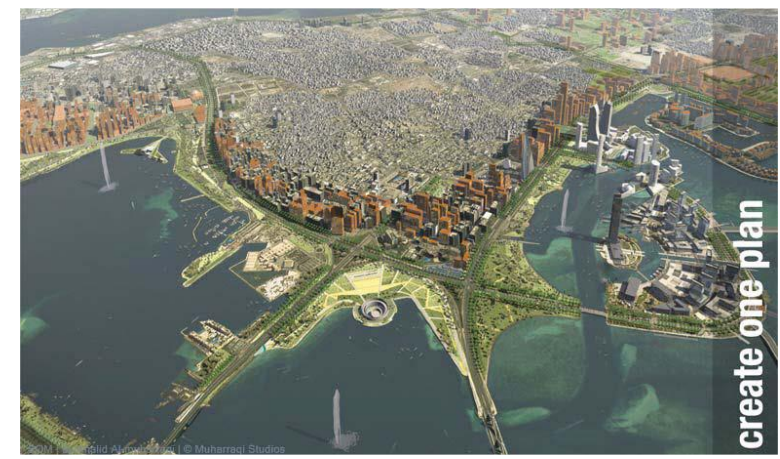

Figure 23: Bahrain's Masterplan 2030 - Overview

\section{Conclusion}

Visual pollution in the old district leads to loss the aesthetics and the sense of unity and common values for the areas in general in terms of:

a. The danger of visual pollution lies in its association with the old district of Manama City. The studied area is a very active pedestrian area, where people constantly use it at all time for the cultural representation it has and the economical center it is, so it is important to have a careful design for the area, which will assure the comfort of the users while using the street.

b. By contrast, the loss of beauty and the collapse of aesthetic considerations in the area deteriorating the general taste of residences in Bab Al Bahrain area, leads to the acceptance of the ugly image as dominate, and deteriorate the taste of the residences.

c. Tourists would never find it appealing to visit the old districts, and the investors and businessmen are to look for other beautiful

\subsection{Benefit of analyzing the Master plan \& Vision of 2030:}

The Master plan \& Vision of 2030 that will help in:

i. "Built distinct communities" and adding greenery to the area

ii. They want to lessen the sprawl, use the land more effectively, help preserve and keep the traditional Bahraini lifestyle, and the historical landmarks.

iii. Protection of the heritage, archaeological, \& cultural sites

iv. Help encourage tourism through visual aesthetics to the archeological sites and traditional Bahraini lifestyle.

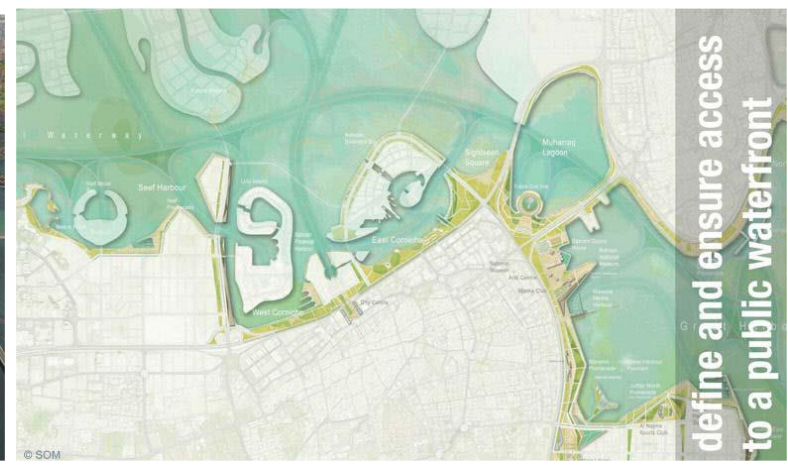

urban context to inaugurate their business. . The real estate investors tend to invest in the reclaimed area opposite to the Manama soug because of sea view and modern infrastructure development.

d. Unpleasant spread until it became a domineering visual characteristic, where law still exists to detect the sources visual pollution and its manifestations in the streets, roads and neighborhoods of the city tracking some aspects.

e. Buildings design are characterized by its haphazard and deteriorating building conditions in terms of installations, color, height, building materials, structure systems, general noticeable exterior and leads to a clear truancy of harmony; utilized materials in covering the facades of buildings, the finishing materials.

f. There is a need to be sure of implementation the approved facades design by the municipality. 
g. Absence respecting traditional architecture style in designing the new building. h. Miss proper Implementing the relation between the followings elements:

Table 1. Visual pollution elements and forms in the old district

\begin{tabular}{|c|c|}
\hline Element & Forms of visual prolusions \\
\hline \multirow{4}{*}{$\begin{array}{l}\text { Site Treatment and Sitting of } \\
\text { buildings }\end{array}$} & Garaging and parking \\
\hline & Communal spaces \\
\hline & Access while health service needed and emergency circumstances. \\
\hline & Private spaces \\
\hline \multirow[t]{5}{*}{ surrounding land-use } & Disappearing the artisan and the traditional workshops area \\
\hline & Access to Commercial land-use \\
\hline & Services (as land-use) \\
\hline & Access to different buildings types (governmental - nongovernmental) \\
\hline & Miss allocating the waste collection \\
\hline \multirow{3}{*}{$\begin{array}{l}\text { infrastructure grid system and } \\
\text { networks }\end{array}$} & improper Sanitary, electricity, communications \\
\hline & Freedom from local hazards and nuisances \\
\hline & Accident hazards. \\
\hline Site furniture & Aesthetics, street lighting, hard scape and soft scape as well \\
\hline \multirow[t]{2}{*}{ Open space (recreational uses } & Public safety \\
\hline & Public recreational places \\
\hline \multirow[t]{3}{*}{ Roads and Transportation } & effective capacity of roads \\
\hline & Access to transportation \\
\hline & Access (vehicles and pedestrians) \\
\hline
\end{tabular}

7. Recommendation:

Authoritative contribution in controlling Visual pollution Urban planning policy level, the flow of the unsorted of the conflict between Bahrain 2030 regarding the enforced regulations and actions amongst local authorities should be curbed, to avoid downgrading the visual quality in old district of Manama city

strategy level, there is a need to revise the points of controlling the visual pollution reasons that mares the beauty of old district of Manama city and gives the viewer an awful display; it should be proposed solutions to mitigate visual pollution. It is worth mentioning, that urban scholars are of authoritative contribution in controlling Visual pollution in Manama Old districts considering the Physical axes, Environmental (context) The social dimension and Economic conditions; (table 1) (El-Ghonaimy, 2013).

Table 2. Influences with phenomena of Visual pollution in Manama Old districts

\begin{tabular}{|l|c|}
\hline \multicolumn{1}{|c|}{ Factor } & Description \\
\hline i- Physical (location) & $\begin{array}{c}\text { Considering applying architecture building code, land use, and landscape architecture } \\
\text { represents the maximum number of users for a certain period in a place without } \\
\text { causing any damage to the environment }\end{array}$ \\
\hline ii- Environment & $\begin{array}{c}\text { Use a level, which you can tolerate without causing any destruction to the environment } \\
\text { and their preservation. }\end{array}$ \\
\hline $\begin{array}{c}\text { iii- social and Cognition } \\
\text { (awareness for users) }\end{array}$ & $\begin{array}{c}\text { Human behavior and resources that Represented by the habits and behaviors, that } \\
\text { characterize the users place (sociological psychological approaches) }\end{array}$ \\
\hline iv- Economic (Returns) & $\begin{array}{c}\text { Activities and management strategies. for example, Accounts for the level of use and } \\
\text { consumption of a place for fuedal returns. } \\
\text { Paying attention to attract capitals and tourists towards the old district. }\end{array}$ \\
\hline
\end{tabular}

Control visual pollution will in term of:

a. Urban design, regulation and coding; there is acute needs to adopt manuals of urban design/architectural guidelines, rules and restoration codes within the protected zones.

b. Skills of Urban Scholars: Raise the technical level of urban designers, landscape architectures and architects responsible to know how to deal with the vernacular buildings in term of Architectural designs, especially façade designs, colors, finishing materials and support section

c. Conservation Zone Area; to adopt temporary visual protection measures 
including two prime protection perimeters for the traditional core areas of Manama. Moreover, to develop the conservation plan leading to the establishment of the urban conservation zones and their boundaries. And to adopt the policy of demonstrating to investors, businessmen, and residents, the government's commitment to these areas through the implementation of pilot projects.

d. Buildings arrangements and locations: prepare strong action roles in controlling the relation between the contractor and the Municipality. Tightening Supervision by municipalities on contractors and owners of the obligation to implement what has been done.

e. Street furniture: there is a need to reexamine the existing case of:

-Street lighting

- Garbage bins

-Soft scape and plants species

- Encouraging walkability

- Fences and barriers

- Sitting areas

- Pavement design

- Allocating bicycles parking

f. Design codes: implement design codes to control schemes, facades, and colors setting suitable landscape architecture.

g. Modern Technology: use it in infrastructure and construction.

h. Encouraging public participation: to share in enhancing and developing the old district.

i. Building designs: Design codes: implement design codes to control:

-Schemes and style of building architecture

- Building materials

-Structure system

- Facades colors and style

- Buildings roofs

- Landscape architecture

\section{Acknowledgment}

Special thanks to Deanship of Graduate Studies and Scientific research for supporting this research paper via Scientific Research Project number 2014/7 and special appreciations for the respecting research assistant Architect Mohamed Elghoneimy, Architect Needa Javed and Architect Huma Mohamed for their efforts within the research.

\section{References}

Agriculture, M. O. (2007). URBAN DESIGN PROJECTS IN TRADITIONAL AREAS. Building for Enhancement Of Urban Governance. Manama: Ministry of Municipalities Affairs and Agriculture. Retrieved from https://www.mun.gov.bh/portal/pages/resear ch/BuildingUrbanEn.jsp

Al-Nabi, Mohammad Noor. (2012). The History of Land use and Development in Bahrain (1 ed., Vol. 1). Manama, Kingdom of Bahrain: Information Affairs Authority. doi:978-99958-0129-8

Bahrain, S. c. (2007). Bahrain National Planning Development Strategy. Manama: SOM consultancy project for Bahrain. Retrieved from https://wiki.epfl.ch/lapastudio/documents/0910 BAH/Sourcebook/BA H-SOM-Masterplan.pdf

Chmielewski, S., Samulowska M., Lupa, M., Lee, D., Zagajewski, B. (2018). Citiezen Science and WebGIS for outdoor advertisement visual pollution assessment. Computers,. Environment and Urban Systems, 67, 97-109. Retrieved from https://www.researchgate.net/publication/32 0086937 Citizen_science_and_WebGIS_for_ou tdoor advertisement visual pollution assessm ent

Chmielewski, Sz., Lee, D., Tompalski, P., Chmielewski, T., J., Wężyk, P. (2016). Measuring visual pollution by outdoor advertisements in an urban street using intervisibilty analysis and public surveys. International Journal of Geographical Information Science, 30(4), 801819.

doi:doi.org/10.1080/13658816.2015.1104316

Dalia Hussain El-Dardiry, Islam Hamdi Elghonaimy. (2005). Urban developing and the environmental policy for the G.C.C. Within GATT arrangements". The G.C.C engineering forum, Bahrain society engineering, Annual Gulf Conferences. 1. Manama, Bahrain: Bahrain society engineering,. Retrieved from http://www.mohandis.org/en/Conferences/Ar chive

Dalia Hussain El-Dardiry, Islam Hamdi Elghonaimy. (2010). Conflict Of Urban Planning Policy And Strategies In Cities Urban Developing. Journal of Assiout University, Engineering Sector. https://www.researchgate.net/publication/32 8518324_CONFLICT_OF_URBAN_PLANNING_PO LICY AND STRATEGIES IN CITIES URBAN DEVE LOPING CASE STUDY MANSOURA CITY EGYPT Islam Hamdi Elghonaimy. (1995, May 12). The relationship between Housing Conditions and unplanned other Land use in Rapidly Growing Urban Areas. Thesis, 1, 1. (1, Ed.) Alexandria, 
Alexandria, Egypt: Alexandria University. Retrieved from https://www.researchgate.net/publication/32 0668111 THE RELATIONSHIP BETWEEN_HOUSIN G_CONDITIONS AND UNPLANNED OTHER LA ND_USES_IN_RAPIDLY_GROWING_AREAS

Islam Hamdi Elghonaimy. (2011). Impacts of Successful experiments in historical preservation projects upon Enhancing City urban conditions; Case of Bahrain. Journal of Al-Azhar University Engineering Sector (JAUES). doi:1 $110-6409$

https://www.researchgate.net/publication/32 5848156 Visual_pollution_phenomena_and_se nsitivity of residences in heritage_city center s_Case_of_Old_district_of_Manama_city_King dom_of Bahrain

Islam Hamdi Elghonaimy. (2013). Landscape Architecture and developing Public Awareness in Saving Energy. Towards Sustainable Development. Kingdom of Bahrain: Bahrain International Exhibition Centre (BIEC),. Retrieved June 17-19, 2013. https://www.researchgate.net/publication/32 5848156 Visual_pollution_phenomena_and_se nsitivity_of residences_in_heritage_city_center s Case of Old district of Manama city King dom_of Bahrain

Islam Hamdi Elghonaimy. (February, 2008). Environmental Impact of Changing in Land Tenure. Symposium of urban planning. 1. Manama, Bahrain: World Bank (WB) and Arab urban development Institute (AUDI. https://www.researchgate.net/publication/32 5848156_Visual_pollution_phenomena_and_se nsitivity_of residences_in_heritage_city_center s_Case_of_Old_district_of_Manama_city_King dom of Bahrain

Islam Hamdi Elghonaimy. (2000, January 12). Monitoring the Changes of Urban Expansion and Land Use Pattern and its Impacts on Residential Areas. PhD thesis, 1, 1. AlMansoura, Dkhalya, Egypt: Al-Mansoura University. Retrieved from https://www.researchgate.net/publication/32 1039541_Monitoring the Changes_of Urban_E xpansion_and_Land_Use_Pattern_and_its_Imp acts_on_Residential_Area

Hamouche, M. B. (2009). Can Chaos Theory Explain Complexity In Urban Fabric? Applications in Traditional Muslim Settlements. NEXUS NETWORK JOURNAL, 11(2), 217- 242. doi:https://doi.org/10.1007/s00004-008-0088-8

Lynch, K. (1960). THE IMAGE OF THE CITY (Twentieth Printime. 1990 ed., Vol. 1). (1, Ed.) Massachusetts, and London, England: The M.I.T. Press. http://www.miguelangelmartinez.net/IMG/pdf
/1960_Kevin Lynch The Image of The City b ook.pdf

Morozan, Cristian; Enache, Elena; Purice, Suzan. (December 2012). "Visual Pollution: A New Axiological Dimension Of Marketing?" (Vol. 1). Brilla, Pite: University of Pite, Faculty of Management-Marketing in Economic Affairs Brilla. Retrieved from https://ideas.repec.org/a/ora/journl/v ly2012i2 p820-826.html

Popular times in Bab Al Bahrain. (2018, 4 2). (google) Retrieved from google maps/timeline:

https://www.google.com/maps/timeline?hl=e n\&authuser $=0$ \&ei $=$ CujzW -

IKIHqau2RtuAG\%3A27\&ved $=1+\% 3 A 17706 \&$ pb

Salim A. El Wazani \& Jose L. Lerma. (July 4, 2006). CAPACITY BUILDING FOR ENHANCEMENT OF URBAN GOVERNANCE URBAN DESIGN PROJECTS FOR TRADITIONAL AREAS (VOI. STAGE 2: URBAN DESIGN PROJECT IN MANAMA BLOCK 301 REPORT ). (U. N. PROGRAM, Ed.) Manama, Capital Governorate, Bahrain: KINGDOM OF BAHRAIN, MINISTRY OF MUNICIPALITIES AFFAIRS \& AGRICULTURE. Retrieved from https://www.mun.gov.bh/portal/pages/resear ch/BuildingUrbanEn.jsp

Uffelen, C. V. (2010). Street Furniture (Vol. 1). (V. Uffelen, Ed., \& C. Talhouni, Trans.) Berlin, , Germany: Braun Publishing AG, The Deutsche Nationalbibliothek

https://www.amazon.com/Street-FurnitureChris-Van-Uffelen/dp/3037680431

Yilmaz, D. (May 2011). In the Context of Visual Pollution: Effects to Trabzon City Center Silhoutte. The Asian Social Science Journal., 7(5), 99. http://contvis.blogspot.com/2013/05/tema-incontext-of-visual-pollution.html 